\title{
INDUSTRIAL ELECTRON ACCELERATORS TYPE ILU
}

\author{
V.L. Auslender, A.A. Bryazgin, V.V. Bezuglov, G.B. Glagolev, V.A. Gorbunov, \\ V.G. Cheskidov, I.V. Gornakov, B.L. Faktorovich, E.N. Kokin, A.N. Lukin, S.A. Maksimov, \\ V.E. Nekhaev, A.D. Panfilov, V.M. Radchenko, N.D. Romashko, A.V. Sidorov, \\ V.O. Tkachenko, A.A. Tuvik, L.A. Voronin \\ BINP SB RAS, Novosibirsk, Russia \\ E-mail:V.O.Tkathenko@inp.nsk.su
}

The paper describes ILU type industrial electron accelerators. Their main parameters, design, principle of action, electron beam extraction devices, wide set of auxiliary equipment for various technological processes and ways of their usage are discussed as well.

PACS: $29.17 .+\mathrm{w}$

\section{INTRODUCTION}

Since 1970, BINP SB RAS has been developing and manufacturing the ILU-type electron accelerators for the work in the research and industrial radiation-technological installations. The design and schematic solutions of the installations envisage a continuous round-theclock operation under conditions of industrial production.

The ILU-type accelerators cover the energy range from 0.7 to $5 \mathrm{MeV}$ at an accelerated beam power of up to $50 \mathrm{~kW}$. The intrinsic features of these accelerators are the simple design, ease in maintenance and the long term reliable operation under conditions of industrial production. Table shows the basic parameters of the ILU-type accelerators produced by BINP [1-3].

Basic parameters of the ILU-type accelerators

\begin{tabular}{|l|c|c|c|c|}
\hline \multicolumn{1}{|c|}{ Parameters } & ILU-6 & ILU-8 & ILU-10 & $\begin{array}{l}\text { ILU-12 } \\
\text { Project }\end{array}$ \\
\hline $\begin{array}{l}\text { Energy of } \\
\text { electrons, MeV }\end{array}$ & $1.2 \ldots 2.5$ & $0.6 \ldots 1.0$ & $2.5 \ldots .5 .0$ & $4.0 \ldots 5.0$ \\
\hline $\begin{array}{l}\text { Average beam } \\
\text { power (max), } \\
\text { kW }\end{array}$ & 20 & 25 & 50 & 300 \\
\hline $\begin{array}{l}\text { Average beam } \\
\text { current (max), } \\
\text { mA }\end{array}$ & 20 & 30 & 15 & 60 \\
\hline $\begin{array}{l}\text { Power } \\
\text { consumption, } \\
\text { kW }\end{array}$ & 100 & 80 & 150 & 700 \\
\hline $\begin{array}{l}\text { Accelerator } \\
\text { weight, tons }\end{array}$ & 2.2 & 0.6 & 2.9 & 5 \\
\hline $\begin{array}{l}\text { Weight of local } \\
\text { protection, tons }\end{array}$ & - & 76 & - & - \\
\hline
\end{tabular}

\section{GENERAL DESCRIPTION}

The basic model of the ILU family is the ILU-6 accelerator [1]. The model ILU-6 is widely used in our country and abroad. This accelerator has rather good parameters at modest dimensions and can be used for wide spectrum of technological processes.
The basic unit of the ILU-6 accelerator is a toroidal copper cavity. It has axial protrusions forming the accelerating gap. The protrusion shape was chosen to form and focus the electron beam so that its injection, acceleration and further passage through the extraction system were performed with minimum losses.

The cavity (1) is placed into the vacuum tank (2) (Fig.1). The electron injector (4) is formed by the cathode unit and the grid mounted in the upper protrusion. The lower electrode and injector form a triode accelerating system.

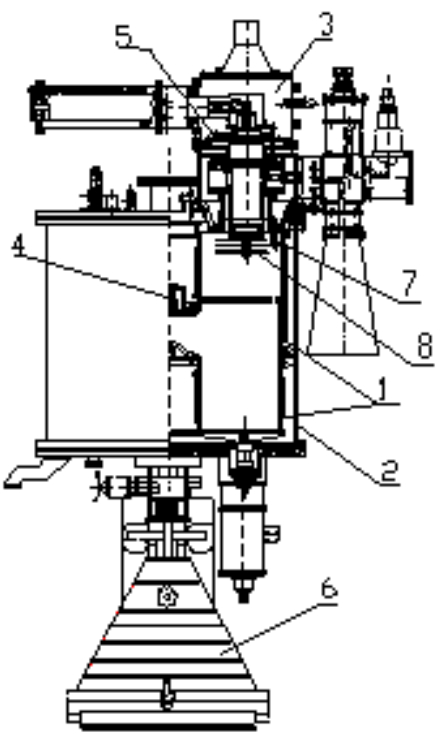

Fig. 1 ILU-6 accelerator

Under the lower electrode of the cavity there is a magnetic lens shaping an electron beam in the accelerator channel and the extraction device 6 .

RF self-exciting generator (3) based on powerful triode type GI-50A is installed directly on the vacuum tank. Generator assembled according to the common grid circuit is working at frequency about $116 \mathrm{MHz}$, that is near the specific frequency of the cavity. Anode circuits are coupled to cavity through the inductance loops. The coupling rate is determined by the square of loop and the tuning of the anode circuits. The generator feedback is provided by the additional capacitance made in the form of a disk, inserted between the tube's anode and cathode. The value of capacitance is about $20 \mathrm{pF}$. The fine tuning of the feedback value and its phase is made by the cathode short-circuited tail with a 
movable shortcut contact moved by a servo-motor. The coupling rate of generator with cavity is tuned during the accelerator's preliminary adjustment by varying the capacity of the vacuum capacitor (8) and the coupling loop square by varying the position of its support (7).

The cavity is placed into the vacuum tank made of stainless steel. The high vacuum pumping is done by four spallation pumps placed at the top and bottom plates of the tank. The forevacuum pumping is provided by the forevacuum aggregate through the nitrogen trap. All the sealings in the vacuum tank are made of metal (copper and indium). The operating vacuum is of $10^{-6}$ Torr. In the normal operation of the accelerator intervals of about two days do not require the forevacuum pumping for switching on the spallation pumps.

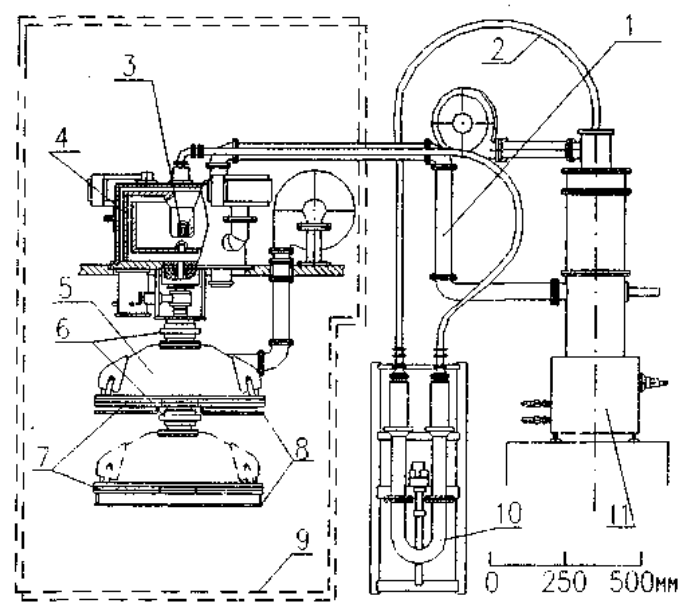

Fig.2. ILU-8 accelerator

Main parameters of the cavity of ILU-6 accelerator are: diameter $-1000 \mathrm{~mm}$, height $-820 \mathrm{~mm}$, resonance frequency - $116.3 \mathrm{MHz}$, accelerating gap length $120 \mathrm{~mm}$, Q-factor - $19.4 \times 10^{3}$, shunt impedance3.5 MOhm. Pulse operating mode as following: pulse duration $-400 \ldots 500 \mu \mathrm{s}$, maximum pulse repetition $50 \mathrm{~Hz}$.

The compact electron accelerator ILU-8 (Fig.2) was built on the base of ILU-6. The technology process of irradiation of tube and wire features was taken in account during this construction.

This accelerator does not require construction of a special protected premise (hall) and can be placed in usual industrial shop. It can work inside the local biological shielding. The local shielding (9) of the accelerator is a kind of a box made of steel plates. This box is divided into two parts. The top part is used to place the accelerating system with RF-cavity (4), spallation vacuum pumps and forevacuum system. The beam extraction device (5), air pipes of ventilation system and technological equipment are placed in the lower part of the shielding. The back wall of the shielding has the channels (labyrinths) for input of cables, air and water pipes. The removable front wall serves as a door of a protective box. The thickness of radiation shielding in side walls part is $330 \mathrm{~mm}$ and in top is $240 \mathrm{~mm}$. Gross weight of shielding is 76 tons.

The cavity excitation is produced by a one-stage self-excited generator with the GI-50A type triode. A feed-back connection (2) through the cavity with a 166 trombon type phase inverter (10) is used. This generator is located out of the local shielding. It is connected with the cavity by a co-axial feeder (1).

Main parameters of cavity resonator of ILU-8 accelerator are: diameter $-700 \mathrm{~mm}$, height $-324 \mathrm{~mm}$, resonance frequency - 176.2 $\mathrm{MHz}$, accelerating gap length $36 \mathrm{~mm}$, Q-factor - $24 \times 10^{3}$, shunt impedance 2.7 MOhm. Pulse operating mode as following: pulse duration $-800 \mu \mathrm{s}$, maximum pulse repetition $-60 \mathrm{~Hz}$.

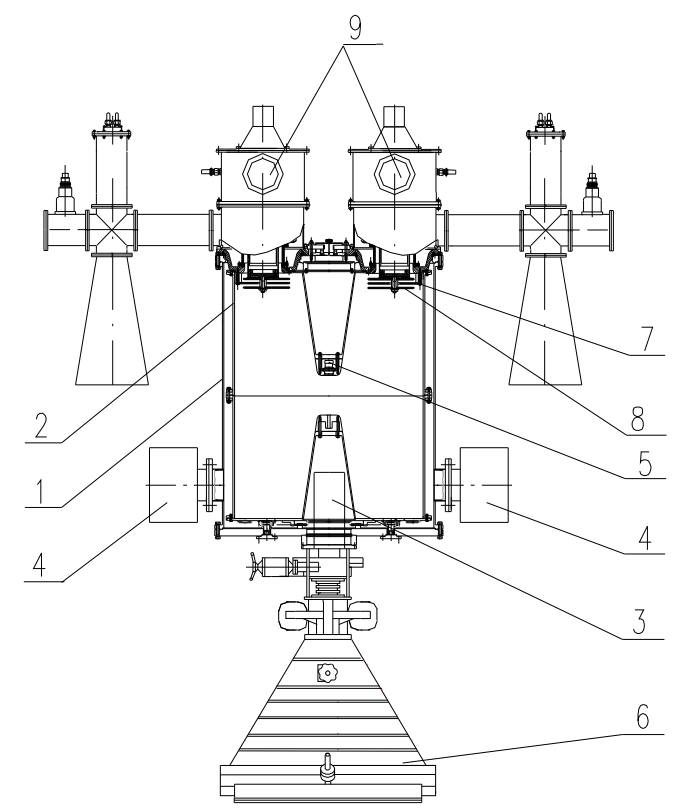

Fig.3. ILU-10 accelerator. 1 - vacuum tank; 2 - copper toroidal cavity; 3 - magnetic lens; 4 -ion pumps; 5 - grid-cathode unit; 6 - beam extraction device with linear scanning; 7-coupling loop support; 8 -vacuum capacitor; $9-R F$ generators

The next development is the ILU-10 accelerator (Fig.3) based also on the ILU-6 accelerator. It was developed to work at energy of $5 \mathrm{MeV}$ required for some technological processes.

In order to decrease high-frequency losses at the same with the ILU-6 resonator resonance frequency, the accelerating gap length and total dimensions of the resonator were increased. The electron accelerator of ILU10 type has two high-frequency generators of ILU-6 type, which operate in parallel for increasing of electron beam power.

The main parameters of cavity of ILU-10 accelerator are: diameter - $1000 \mathrm{~mm}$, height $-1300 \mathrm{~mm}$, resonance frequency $-115.9 \mathrm{MHz}$, accelerating gap length - $270 \mathrm{~mm}$, Q-factor - $28 \times 10^{3}$, shunt impedance $8 \mathrm{MOhm}$.

\section{BEAM INJECTION}

As mentioned above, the use of the internal injection, when the cathode with the control grid is placed directly at the accelerating gap entrance, is the ILU-type accelerator's feature. The opposite electrode of the cavity acceleration gap is used as an anode.

The grid-cathode unit is located on the upper electrode directly at the accelerating gap entrance (Fig.2). The triode gun consists of the cathode, control grid and 
lower accelerating gap electrode performing the role of the anode. The grid and upper electrode are the united peace made of copper. The cathode unit is installed on the insulator ahead of the grid. The $16 \mathrm{~mm}$ diameter cathode tablet is made of lanthanum hexaboride $\left(\mathrm{LaB}_{6}\right)$. The cathode heating is provided by a cone helix heater made of tungsten wire of $0.6 \mathrm{~mm}$ diameter heated by current of $20 \mathrm{~A}$, the working voltage being $12 \ldots 15 \mathrm{~V}$. The anode hole has $30 \mathrm{~mm}$ diameter. A magnetic lens is installed under the lower electrode allowing the beam transverse size at the output device entrance to be controlled. In this injection method the beam current is formed by RF field penetrating into the grid-cathode gap from the accelerating gap and is determined by the grid penetration factor.

\section{ELECTRON BEAM EXTRACTION}

The pulse nature of an electron beam generated by ILU machines permits designing of beam extraction devices for radiation technologies forming the irradiation zones for multilateral irradiation of objects of various forms. It enables one to increase the beam usage efficiency and in some cases to reduce the electron energy required for irradiation, or to expand the nomenclature of treated products.

The beam extraction device for extraction of electrons into air is attached to the vacuum tank's lower flange through a separating valve. The electron beam extracted into the air through foil. Usually, three types beam extraction device can be used: linear scanning device for treatment of flat product, 3-window extraction device for 4-side tube or cable irradiation [4] and beam extraction device with X-ray converter [5].

In the linear scanning device each pulse of the beam is scanned along the length of extraction window (Fig.1). In the 3-window extraction device beam pulses are scanned sequentially along its upper windows and along the left and right parts of lower window (Fig.2).

\section{CONCLUSIONS}

The important directions in activities of Institute of Nuclear Physics are medical, biological, and pharmacological applications of our accelerators. The electron beam sterilization technology for disposal medical products is well studied and widely used in our country and abroad. This technology was developed as an alternative to the gamma irradiation by the installations with Co and Cs isotopes. The ILU-10 accelerator can work with maximum energy of $5 \mathrm{MeV}$, ideally suites for the irradiation centres purposed for treatment of wide spectrum of goods. The electron energy of $5 \mathrm{MeV}$ permits to treat the products that can have the surface density up to $4 \mathrm{~g} / \mathrm{cm}^{2}$ if the two-sided irradiation is organized. It means that the products can be treated in the packed form - in the cartoon boxes containing the several sets of products.

The maximum beam power of ILU-10 accelerator is $50 \mathrm{~kW}$, so the productive rate of the irradiation facility can be up to $300 \ldots 700 \mathrm{~kg}$ per hour assuming the sterilization dose of $25 \mathrm{kGy}$.

It is need to say, more than 30 ILU-type accelerators were produced and delivered to the different organizations and industrial plants in Russia, Ukraine, Belarus, Poland, Czech Republic, Hungary, Italy, Romania, Japan, China, South Korea, India and Cuba.

\section{REFERENCES}

1. V.L. Auslender. ILU-type electron accelerator for industrial technologies // Nucl. Instr. and Methods. 1984, B89, p.46-48.

2. V.L. Auslender, R.A. Salimov. Electron accelerators of INP SB AS USSR for national economy // Atomnaja energija. 1978, v.44, №5, p.403-408.

3. V.L. Auslender et al. Electron Accelerator for Energy up to $5.0 \mathrm{MeV}$ and Beam Power up to $50 \mathrm{~kW}$ with X-ray Converter // Problems of Atomic Science and Technology. Series: Nuclear Physics Investigations. 2004, №1(42), p.21-23.

4. V.L. Auslender, V.E. Nekhaev, A.D. Panfilov, A.A. Tuvik. Compact ILU-type electron accelerator as a base for industrial 4-sided irradiation systems for cable and tubes // Radiation Physics and Chemistry. 1999, v.54, p.609-618.

5. V.L. Auslender, A.D. Bukin, L.A. Voronin et al. Bremsstrahlung convertors for powerful industrial electron accelerators. Proc. of the $13^{\text {th }}$ Intern. Meeting on Radiation Processing (IMRP). 2004, v.71, №1-2, p.297-299.

\title{
ПРОМЫШЛЕННЫЕ УСКОРИТЕЛИ ЭЛЕКТРОНОВ СЕРИИ ИЛУ
}

\author{
В.Л. Ауслендер, А.А. Брязгин, В.В. Безуглов, Г.Б. Глаголев, В.А. Горбунов, В.Г. Ческидов, И.В. Горнаков, \\ Б.Л. Факторович, Е.Н. Кокин, А.Н. Лукин, С.А. Максимов, В.Е. Нехаев, А.Д. Панфилов, В.М. Радченко, \\ Н.Д. Ромашко, А.В. Сидоров, В.О. Ткаченко, А.А. Тувик, Л.А. Воронин
}

Описаны промышленные ускорители электронов серии ИЛУ. Приведены основные параметры, устройство и принцип действия. Дается краткое описание систем выпуска ускоренного пучка в атмосферу для различных технологических процессов.

\section{ПРОМИСЛОВІ ПРИСКОРЮВАЧІ ЕЛЕКТРОНІВ СЕРІЇ ІЛП}

\section{В.Л. Ауслендер, А.А. Бряздін, В.В. Безуглов, Г.Б. Глаголев, В.А. Горбунов, В.Г. Ческідов, І.В. Горнаков, Б.Л. Факторович, С.Н. Кокін, А.Н. Лукін, С.А. Максімов, В.С. Нехаєв, А.Д. Панфілов, В.М. Радченко, Н.Д. Ромашко, А.В. Сидоров, В.О. Ткаченко, А.А. Тувік, Л.А. Воронін}

Описано промислові прискорювачі електронів серії ЫЛП. Наведено основні параметри, будова і принцип дії. Дається короткий опис систем випуску прискореного пучку в атмосферу для різних технологічних процесів. 
